\title{
Temperature and light responses of alga Caulerpa taxifolia introduced into the Mediterranean Sea
}

\author{
Teruhisa Komatsu ${ }^{1,2,}$, Alexandre Meinesz ${ }^{1}$, Daphne Buckles ${ }^{1,3}$ \\ ${ }^{1}$ Laboratoire Environnement Marin Littoral, CNRS UMR 6540, Université de Nice-Sophia Antipolis, F-06108 Nice Cedex 2, France \\ ${ }^{2}$ Ocean Research Institute, University of Tokyo, 1-15-1, Minamidai, Nakano-ku, Tokyo 164, Japan \\ ${ }^{3}$ Division of Natural Science, Southampton College, Long Island University, Southampton, New York 11968, USA
}

\begin{abstract}
Cuttings of Mediterranean Caulerpa taxifolia were cultured under controlled temperature and light conditions in culture chambers. The upper lethal temperature was between 31.5 and $32.5^{\circ} \mathrm{C}$ and the lower lethal temperature between 9 and $10^{\circ} \mathrm{C}$. Between 10 and $12.5^{\circ} \mathrm{C}$, the alga survived without any growth; new stolons and new fronds developed at 15 and $17.5^{\circ} \mathrm{C}$, respectively. Stolon growth was strongly correlated with the temperature increase. No morphological changes were observed when the cuttings were cultured within the vital temperature range $\left(10\right.$ to $\left.31.5^{\circ} \mathrm{C}\right)$. The new fronds and stolons developed on the cuttings under a very weak light intensity of photosynthetically active radiation $\left(27 \mu \mathrm{mol} \mathrm{m} \mathrm{m}^{-2} \mathrm{~s}^{-1}\right.$ at a photoperiod cycle of $14 \mathrm{~h}$ light:10 h dark). The most favorable range of light intensity was between 88 and $338 \mu \mathrm{mol} \mathrm{m}^{-2} \mathrm{~s}^{-1}$ (14 h light:10 h dark). These light and temperature responses confer to the Mediterranean strain C taxifolia, introduced in 1984, a large potential for expansion throughout the Mediterranean Sea and also in adjacent tropical and temperate seas.
\end{abstract}

KEY WORDS: Caulerpa taxifolia Mediterranean Sea Temperature Light

\section{INTRODUCTION}

Introduced into the Mediterranean Sea at Monaco in 1984 (Meinesz \& Boudouresque 1996), the tropical Caulerpa taxifolia (Vahl) C. Agardh is continuously spreading each year (Meinesz \& Hesse 1991, Meinesz et al. 1993, 1994a). The affected areas were estimated at $1 \mathrm{~m}^{2}$ in 1984,3 ha in 1990 (year of discovery in France), 30 ha in 1991, 427 ha in 1992 (year of discovery in Italy and Spain), 1300 ha in 1993 and 1500 ha at the end of 1994. In February 1995 it was first discovered in Croatia (Adriatic Sea). Actual findings showed that the principal mode of reproduction of C. taxifolia in the Mediterranean Sea is vegetative (Meinesz 1992). Furthermore, the dispersion of cuttings may occur either naturally in the immediate area of a colonized site, or artificially at greater distances by means of pleasure boat anchorings or fishing nets (Meinesz 1992, Sant et al. 1994).

To define potential habitat range limits, we analyzed the effects of temperature and light on the growth and

\footnotetext{
•E-mail:komatsu@ori.u-tokyo.ac.jp
}

development of cuttings of Caulerpa taxifolia cultured in culture chambers. Furthermore, culturing of C. taxifolia under these various conditions will allow us to assess possible morphological ecotypical variations.

\section{MATERIAL AND METHODS}

The material was collected using SCUBA on the day before the start of each experiment. The sampling site was in the recreational harbour of La Darse (Villefranche-sur-Mer, France: $\left.43^{\circ} 41.98^{\prime} \mathrm{N}, 7^{\circ} 18.60^{\prime} \mathrm{E}\right)$, where a colony, which in May 1996 covered more than 1 ha, has developed since 1992 between 3 and $6 \mathrm{~m}$ depth.

A complete thallus of Caulerpa taxifolia is composed of a ramified stolon which can reach more than $2 \mathrm{~m}$ in length and can carry more than 100 fronds and as many as 100 rhizoid pillars (Meinesz et a.1. 1995). These individuals are strongly fixed to the substrate by a dense network of fine rhizoids. It is therefore difficult to remove entire individuals of this alga without breakage. The effects of light and temperature on the devel- 
opment and growth were evaluated from generated parts on stolons and fronds of 2 types of cutting units: 'isolated frond segments' (5 $\mathrm{cm}$ apical part of a frond) and 'thallus fragments' ( 8 or $10 \mathrm{~cm}$ of stolon carrying 2 to 4 fronds) (Fig. 1).

The experimental specimens were set in aquaria containing $4 \mathrm{l}$ of seawater, previously filtered and sterilized in an autoclave. The seawater, analyzed at the start of the experiments, contained less than $0.16 \mathrm{mg}$ $\mathrm{l}^{-1}$ of nitrates and less than $0.1 \mathrm{mg} \mathrm{l}^{-1}$ phosphates.

The aquaria were kept in culture chambers equipped with 3 fluorescent lamps (Thorn, Model 16H06) attached to the upper panel of the culture chamber The underwater light intensity was measured with a LI-COR waterproof spherical sensor at the level at which the alga lay in each of the aquaria which were placed on 3 different shelves in the culture chamber Photosynthetically active radiation (PAR) varied from 27 to $356 \mu \mathrm{mol} \mathrm{m} \mathrm{m}^{-2} \mathrm{~s}^{-1}$ depending on the different configurations (number of lamps, and position and number of aquaria) in the culture chamber. Different photo-

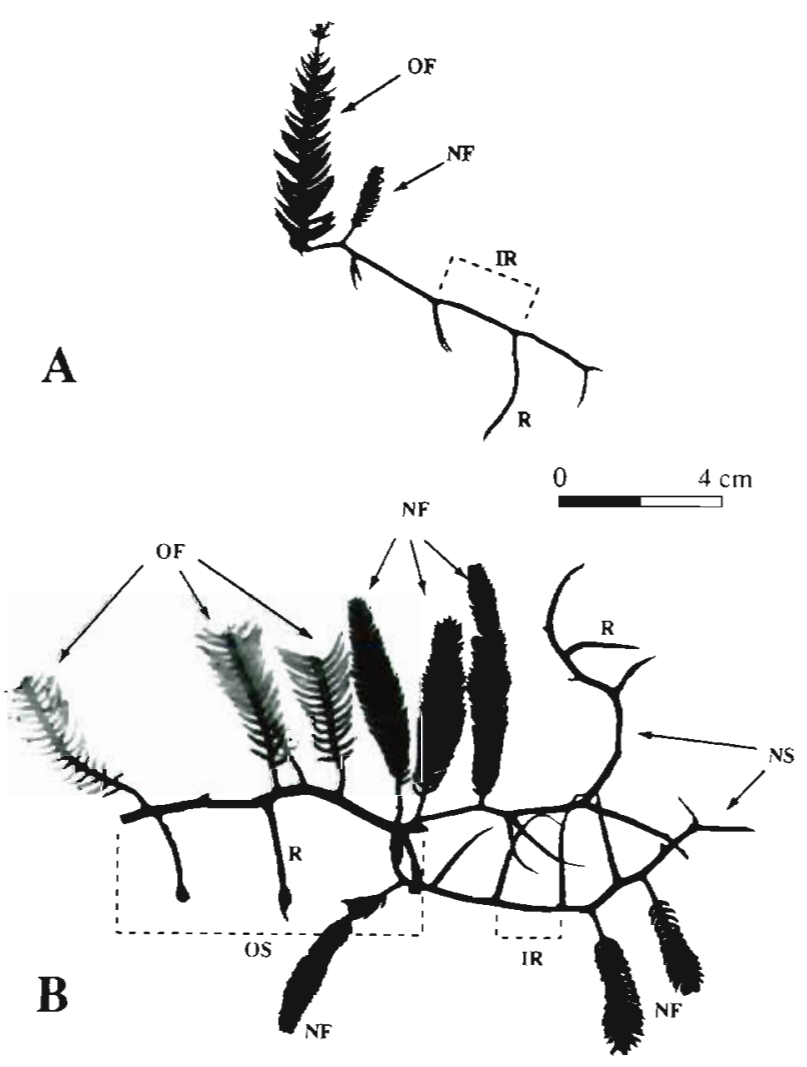

Fig. 1. Caulerpa taxifolia. (A) Isolated frond segment $(5 \mathrm{~cm})$ after a $10 \mathrm{~d}$ culture period at $25^{\circ} \mathrm{C}$. (B) Thallus fragment $(8 \mathrm{~cm}$ stolon carrying 4 fronds) after a $10 \mathrm{~d}$ culture period at $27.5^{\circ} \mathrm{C}$. $O F$ : original frond; NF: new frond; OS: original stolon; NS: new stolon; R: pillar of rhizoids; IR: interval between 2 pillars of rhizoids period cycles of $8: 16,10: 14,12: 12,14: 10$, and $16: 10 \mathrm{~h}$ (light:dark) were tested.

Experimental temperatures ranged from 6 to $34^{\circ} \mathrm{C}$ The temperature of the water in the aquaria, measured every day, varied $\pm 0.2^{\circ} \mathrm{C}$ in relation to the desired temperature. To avoid thermal shock, we always acclimated the cuttings; 2 to $5 \mathrm{~d}$ were necessary to progressively decrease or increase the temperature until the desired temperature was reached. Such a precaution is recommended for this type of experiment (e.g. Novaczek et al. 1989). When the acclimation period was completed, an initial state of cutting morphology was established; photographs of the samples were used as references.

The cultures, under precise light and temperature conditions, were maintained for periods between 10 and $90 \mathrm{~d}$ in duration; the samples were again photographed or fixed in a herbarium.

A total of 24 aquaria in 3 culture chambers were used, and 20 isolated frond segments were used per aquarium. We used 2 or 4 thallus fragments per aquarium, maintaining them in their natural position (stolon along the bottom and fronds vertical) using transparent, plastic separators.

The following measurements were taken: (1) the quantity, length, and diameter of the new stolons; (2) the quantity of the new rhizoid pillars and their spacing on the stolon; and (3) the quantity and size (length) of the new fronds.

\section{RESULTS}

\section{Lethal temperature experiments}

To determine the maximum and minimum temperatures at which the alga can survive, we used a long day photoperiod cycle $(16: 8 \mathrm{~h})$ with high temperatures $(30$, $31,31.5,31.7,32,32.5^{\circ} \mathrm{C}$ ) and a short day photoperiod cycle $(8: 16 \mathrm{~h})$ with low temperatures $\left(6,7,9,10,12^{\circ} \mathrm{C}\right)$. In both cases, a weak light intensity was used (between

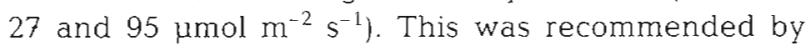
Cambridge et al. (1984), Yarish et al. (1984, 1986) and Novaczek et al. (1989). Twenty cuttings of isolated frond segments were used for each temperature tested.

Between 30 and $31^{\circ} \mathrm{C}$, the cuttings grew and developed. At $31.5^{\circ} \mathrm{C}, 8$ cuttings of isolated frond segments were dead after $1 \mathrm{wk}$ of culture; the other frond segments developed new stolons and survived a $20 \mathrm{~d}$ culture period. At $31.7^{\circ} \mathrm{C}$, only 4 cuttings of isolated frond segments survived after $20 \mathrm{~d}$, and at $32^{\circ} \mathrm{C}$, only 1 frond survived. At $32.5^{\circ} \mathrm{C}$, all of the fronds died within the first week of culture. At this temperature, the same result was obtained with photoperiod cycles of 12:12 and 16:8 h. 
For the lower temperatures, we first noticed the absence of development and growth of the cuttings at 10 and $12^{\circ} \mathrm{C}$. Resistance to the lowest temperatures was observed for short periods of time because the cuttings could not remain alive for longer. After $10 \mathrm{~d}$ at $7^{\circ} \mathrm{C}$ or $1 \mathrm{wk}$ at $6^{\circ} \mathrm{C}$, algal growth resumed when the temperature was slowly brought back to $18^{\circ} \mathrm{C}$. The isolated frond segments resisted for 3 mo at $10^{\circ} \mathrm{C}$ and then developed after raising of the temperature to $18^{\circ} \mathrm{C}$. However, all of the isolated frond segments maintained at $9^{\circ} \mathrm{C}$ were dead in less than 2 mo. Thus, the coldest experimental lethal temperature for a period of $3 \mathrm{mo}$ is between 9 and $10^{\circ} \mathrm{C}$.

The temperature responses of the Caulerpa taxifolia introduced into the Mediterranean Sea are summarized in Fig. 2. It gives the thermal tolerances of the alga that grew between 15 and $31.5^{\circ} \mathrm{C}$ and of those that were able to survive between 10 and $15^{\circ} \mathrm{C}$ for $3 \mathrm{mo}$.

\section{Effects of temperature on growth and development}

We tested the effect of temperature under defined light conditions $\left(193 \pm 26 \mu \mathrm{mol} \mathrm{m} \mathrm{m}^{-2} \mathrm{~s}^{-1}\right)$. The photoperiod was $12: 12 \mathrm{~h}$ for the following temperatures: 10 , $12.5,15,17.5,20,22.5,25,27.5,30$ and $32.5^{\circ} \mathrm{C}$. Twenty isolated frond segments and 6 thallus fragments were used for each temperature. Results were recorded after a $10 \mathrm{~d}$ culture period.

\section{Development and growth of the stolons}

Growth rates of new stolons were similar on both types of cuttings (isolated frond segments and thallus fragments) (Fig. 3). Nevertheless, the average total length of new stolon for 1 cutting was close to 4 times greater on the thallus fragments (larger cuttings) than on the isolated frond segments.

At 10 and $12.5^{\circ} \mathrm{C}$, no development of new stolons or fronds was observed on the cuttings which remained in a good condition (no necrosis). At $32.5^{\circ} \mathrm{C}$, all of the cuttings had died after $5 \mathrm{~d}$. Within the temperature range of 15 to $30^{\circ} \mathrm{C}$, new stolons appeared on all the cuttings.

The length of the new stolons increased in direct proportion to the temperature (Fig. 3). The largest mean length of new stolons was $61.7 \mathrm{~mm}$ (SD = $16.8 \mathrm{~mm}$ ) at $30^{\circ} \mathrm{C}$ on isolated frond segments over $10 \mathrm{~d}$ and was $240.7 \mathrm{~mm}(\mathrm{SD}=42.13 \mathrm{~mm})$ at $27.5^{\circ} \mathrm{C}$ on thallus fragments for the same culture period.

On the isolated frond segments, most of the stolons $(95 \%)$ appeared on the distal cut section (Fig. 1A),

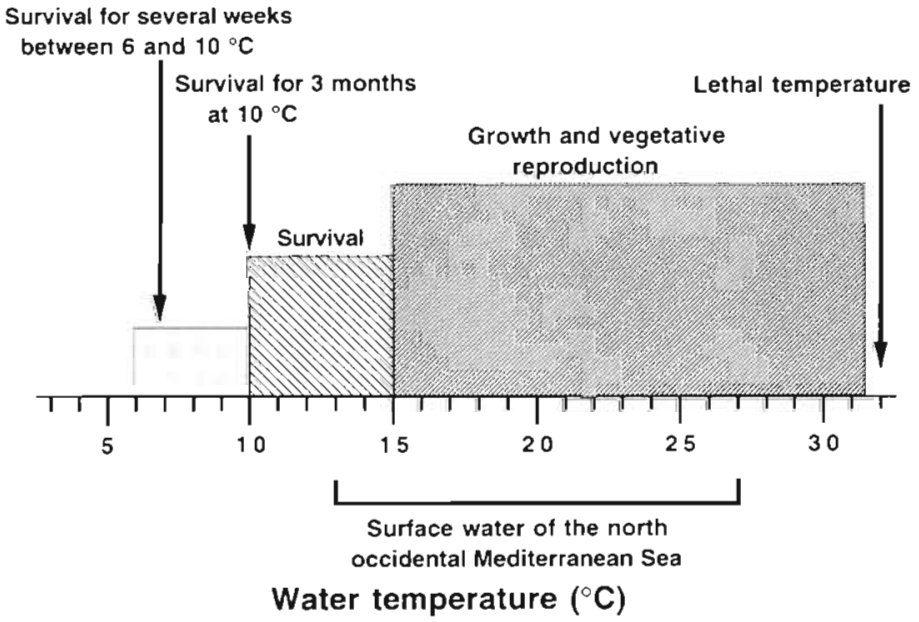

Fig. 2. Temperature responses of the Mediterranean strain of Caulerpa taxifolia

which demonstrated a very marked polarity. We also noticed that the diameter of the new stolons decreased as the temperature increased (Fig, 4). The 1-way ANOVA test rejected the 2 null hypotheses, homo-
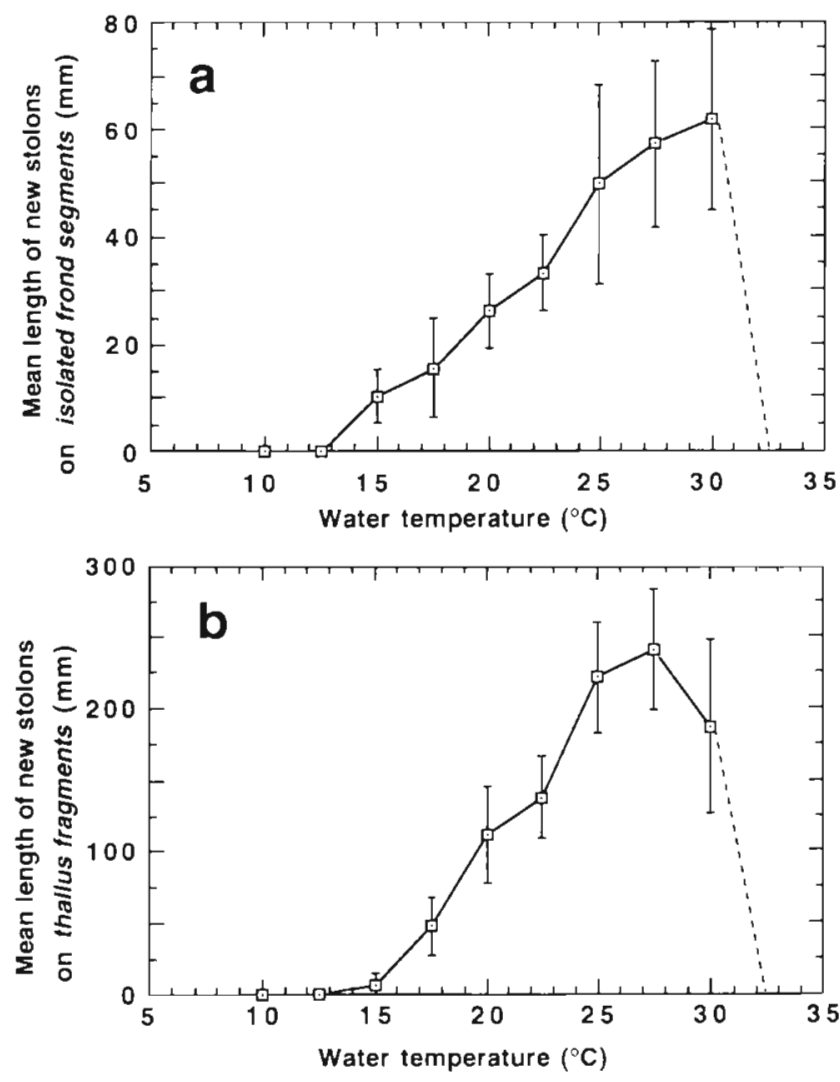

Fig. 3. Mean length \pm SD of new stolons on (a) each isolated frond segment $(n=20)$ and (b) each thallus fragment $(n=6)$ after a $10 \mathrm{~d}$ culture period at different temperatures. Light: 12:12 h (light:dark), $193 \pm 26 \mu \mathrm{mol} \mathrm{m} \mathrm{m}^{-2} \mathrm{~s}^{-1}$ Dashed lines show that all the cuttings died after the culture period 


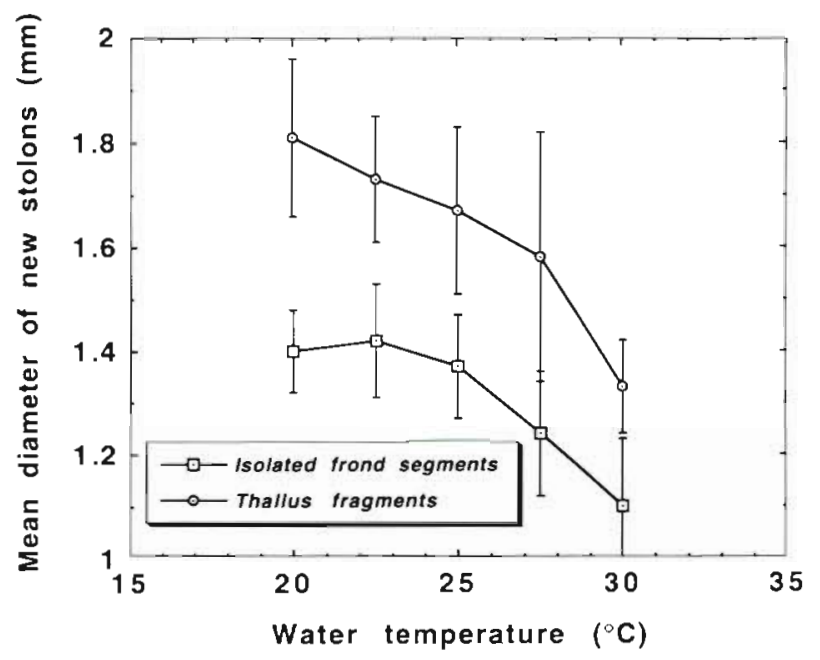

Fig. 4. Mean diameter \pm SD of the new stolons on the 2 types of cuttings at different temperatures after a $10 \mathrm{~d}$ culture

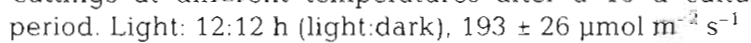

geneity of means of diameter of new stolons on the isolated frond segments and on the thallus fragments among 5 temperature groups ( $\mathrm{df}=4, F=36.68, \mathrm{p}<$ 0.0001 and $\mathrm{df}=4, F=20.36, \mathrm{p}<0.0001$, respectively). with the SAS statistical package program (SAS Inc.) Then, we made multiple comparison tests for means to examine which temperature groups equally affected growth of stolons on the 2 types of cuttings using the Student-Newman-Keuls test in the SAS statistical package program. It was suggested that the abrupt decrease in the mean diameter of new stolons above $27.5^{\circ} \mathrm{C}$ on the isolated frond segments and above $30^{\circ} \mathrm{C}$ on the thallus fragments was statistically significant (Table 1). Thus it was concluded that the most favorable temperature for new stolon growth was $27.5^{\circ} \mathrm{C}$ on a basis of length and diameter of new stolons.

\section{Development of the fronds}

The development of new fronds on the cuttings was less regular and more sensitive to temperature variations (Fig. 5). At $10,12.5$, and $15^{\circ} \mathrm{C}$, there was no development of new fronds on the 2 types of cuttings tested. For the cuttings composed of isolated frond segments, we obtained a small number of new fronds at $1.7 .5^{\circ} \mathrm{C}(4$ of 20 isolated frond segments) and none at $20^{\circ} \mathrm{C}$ (Fig. 5a). For the thallus fragments, new fronds appeared only at $20^{\circ} \mathrm{C}$ (Fig. 5b). These fronds appeared as much on the initial fragment of the stolon as on the new stolons (Fig. 1B). Of all water temperatures tested, numbers of new fronds on the 2 types of cuttings cultured (isolated frond segments and thallus fragments) were the greatest, 1.3 and 4 respectively, at $27.5^{\circ} \mathrm{C}$ after a $10 \mathrm{~d}$ culture period.
Table 1 Results of the Student-Newman-Keuls multiple comparison test to examine the differences between all of the possible pairs of the means of diameter of new stolons on isolated frond segments and isolated thallus fragments cultured at different water temperatures. Light: 12:12 h (light:dark), $193 \pm 26 \mu \mathrm{mol} \mathrm{m} \mathrm{m}^{-2} \mathrm{~s}^{-1}$ Isolated frond segments: $\mathrm{df}=103$, $\mathrm{MSE}=0.012377, \alpha=0.05$; thallus fragments: $\mathrm{df}=54, \mathrm{MSE}=$ $0.023109, \alpha=0.05$. A, B and C represent statistically different groups

\begin{tabular}{|lcccccc|}
\hline Water temperature $\left({ }^{\circ} \mathrm{C}\right):$ & 20 & 22.5 & 25 & 27.5 & 30 \\
\hline isolated frond segments (no.) & 20 & 20 & 20 & 19 & 29 \\
& A & A & A & B & C \\
Thallus fragments (no.) & 12 & 7 & 15 & 9 & 16 \\
& A & A & A & & \\
& & B & B & B & C \\
\hline
\end{tabular}
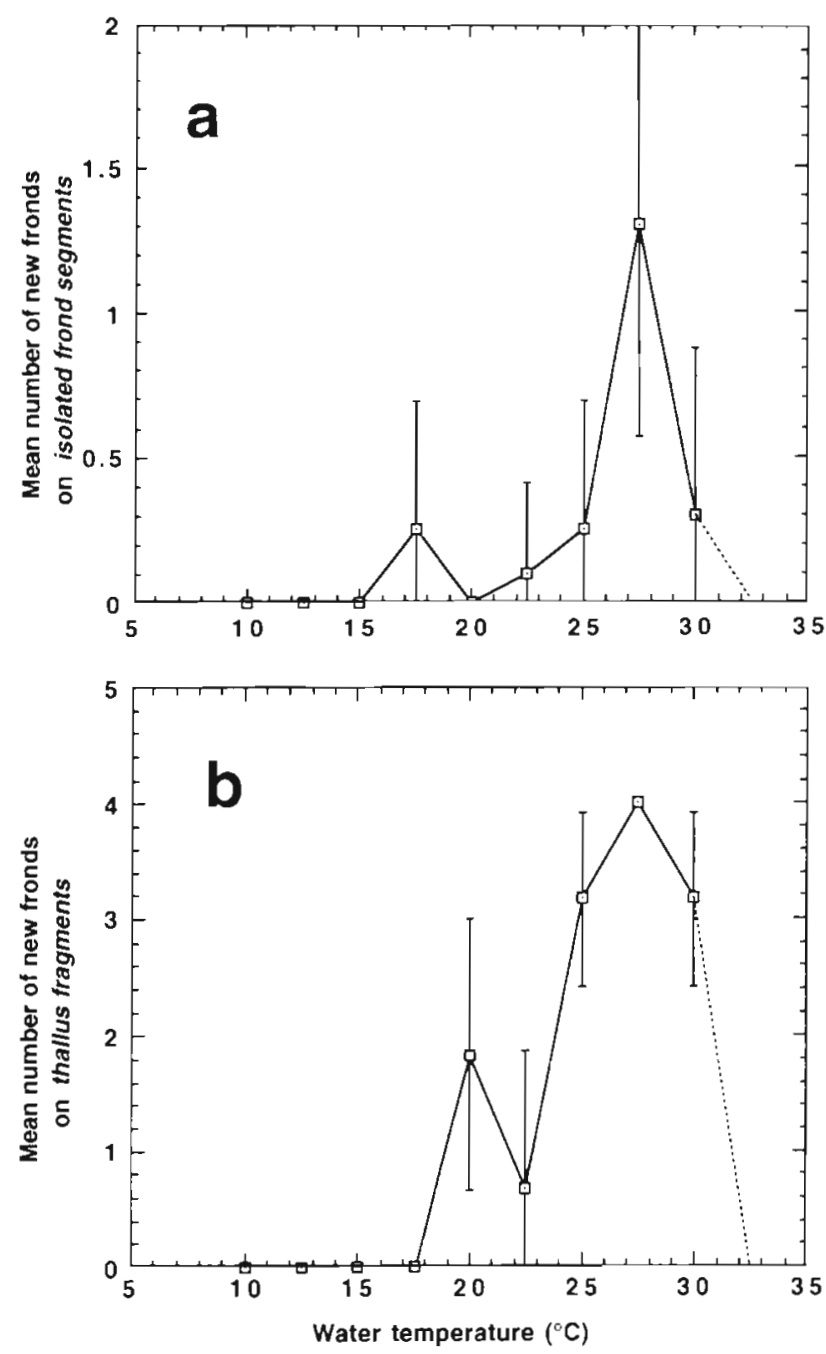

Fig. 5. Mean number \pm SD of new fronds on (a) each isolated frond segment $(n=20)$ and (b) each thallus fragment $(n=6)$ after a $10 \mathrm{~d}$ culture period at different temperatures. Light: 12:12 h (light:dark), $193 \pm 26 \mu \mathrm{mol} \mathrm{m} \mathrm{m}^{-2} \mathrm{~s}^{-1}$ Dashed lines show that all the cuttings died after the culture period 


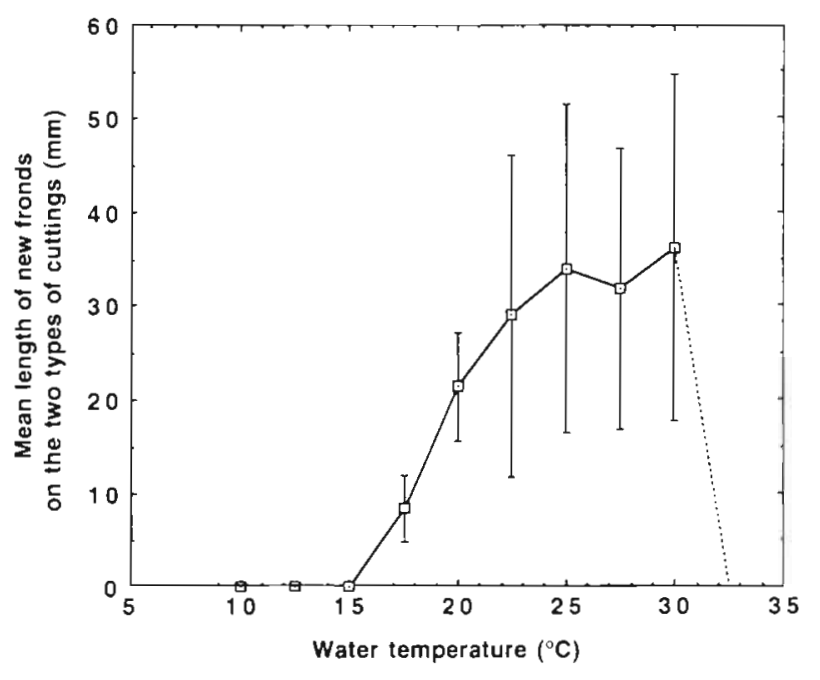

Fig. 6. Mean length \pm SD of the new fronds on the 2 types of cuttings at different temperatures after a $10 \mathrm{~d}$ culture period. Light: $12: 12 \mathrm{~h}$ (light:dark). $193 \pm 26 \mu \mathrm{mol} \mathrm{m} \mathrm{m}^{-2} \mathrm{~s}^{-1}$ Dashed line shows that all the cuttings died after the culture period

\section{Growth of the fronds}

The average length of the new fronds was similar between 20 and $30^{\circ} \mathrm{C}$ (Fig. 6), but most of the new fronds did not terminate their growth after the $10 \mathrm{~d}$ culture period. The greatest lengths were obtained at $30^{\circ} \mathrm{C}$ where some new fronds reached lengths of $10 \mathrm{~cm}$ (Fig. 7).

\section{Effects of light on growth and development}

To test the effect of light, cuttings were cultured at a temperature favorable to growth and development: $25^{\circ} \mathrm{C}$.

Fig 8 shows that the growth of new stolons on thallus fragments showed higher development of new stolons in the range of light intensities above $88 \mu \mathrm{mol}$ $\mathrm{m}^{-2} \mathrm{~s}^{-1}$ (photoperiod cycle of 14:10 h). Development of new stolons on isolated frond segments decreases at light intensities greater than $17.94 \mathrm{~mol} \mathrm{~m}^{-2} \mathrm{~d}^{-1}$, equivalent to $356 \mu \mathrm{mol} \mathrm{m} \mathrm{m}^{-2} \mathrm{~s}^{-1}(14: 10 \mathrm{~h}$ ) (Fig. 9). The 1-way ANOVA test rejected the null hypothesis, homogeneity of means of length of new stolons on the thallus fragments and of means of length of new stolons on the isolated frond segments among 9 light intensity groups $(\mathrm{df}=8, F=5.12, \mathrm{p}<0.0001$ and $\mathrm{df}=8, F=$ 10.87, $p<0.0001$, respectively), with the SAS statistical program package. Then, multiple comparison tests for means were conducted to examine which light intensity groups equally affect growth of stolons on the 2 types of cutting units (data sets of Figs. 8 \& 9) using the Student-Newman-Keuls test in the SAS

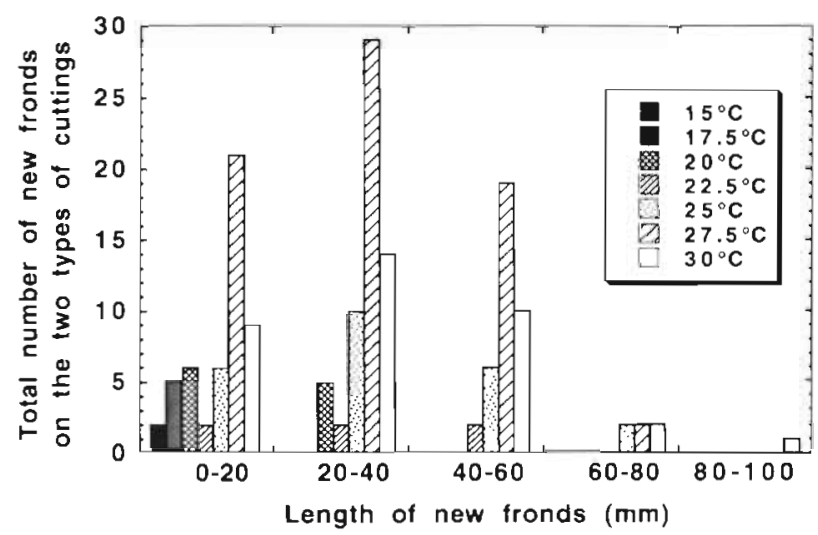

Fig. 7 Frequency distribution of new frond length on the 2 types of cuttings at different temperatures after a $10 \mathrm{~d}$ culture period. L.ıght: $12: 12 \mathrm{~h}$ (light:dark), $193 \pm 26 \mu \mathrm{mol} \mathrm{m}{ }^{-2} \mathrm{~s}^{1}$

statistical package program. The mean lengths of new stolons on the thallus fragments cultured above $88 \mu \mathrm{mol} \mathrm{m} \mathrm{m}^{-2} \mathrm{~s}^{-1}$ were statistically the largest of all the new stolons (Table 2). Table 3 suggests that the mean length of new stolons on the isolated frond segments cultured at $17.94 \mathrm{~mol} \mathrm{~m} \mathrm{~m}^{-2} \mathrm{~d}^{-1}$ was statistically smaller than those between 12.8 and $15.4 \mathrm{~mol} \mathrm{~m} \mathrm{~m}^{-2} \mathrm{~d}^{-1}$. The growth of new stolons on the thallus fragments was observed at the weak light intensities of 27 and $55 \mu \mathrm{mol} \mathrm{m} \mathrm{m}^{-2} \mathrm{~s}^{-1}$ (photoperiod cycle of 14:10 h) equivalent to 1.36 and $1.98 \mathrm{~mol} \mathrm{~m}^{-2} \mathrm{~d}^{-1}$.

On the thallus fragments ( $n=2$ ), cultured for $40 \mathrm{~d}$ (photoperiod cycle of 14:10 h), some new fronds developed on the new stolons. Fig. 10 shows that the number of new fronds increased with stronger irradiation.

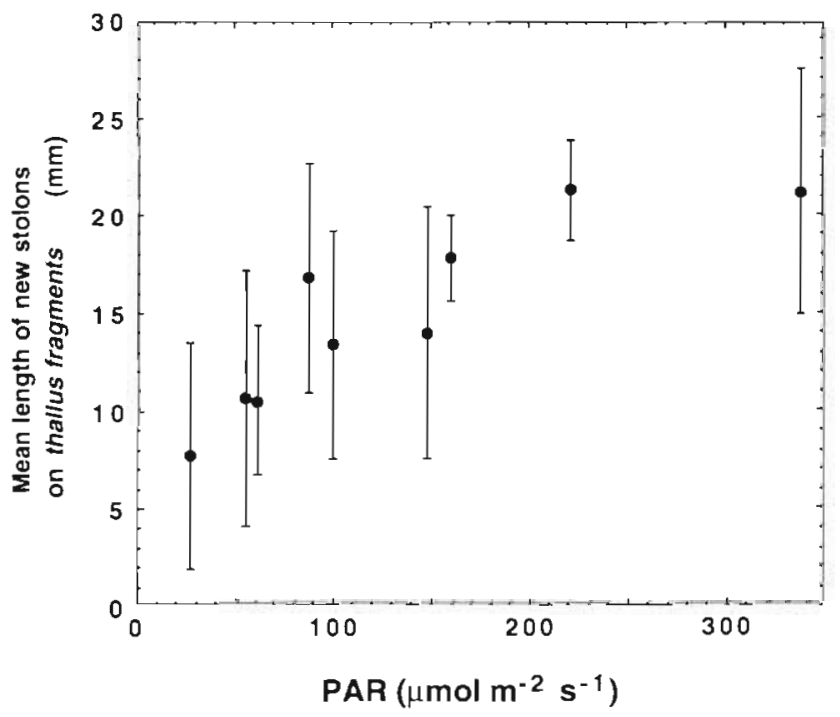

Fig. 8. Mean length \pm SD of new stolons on each thallus fragment $(\mathrm{n}=2)$ after a $20 \mathrm{~d}$ culture period at different light intensities with $14: 10 \mathrm{~h}$ (light:dark) at $25^{\circ} \mathrm{C}$ 


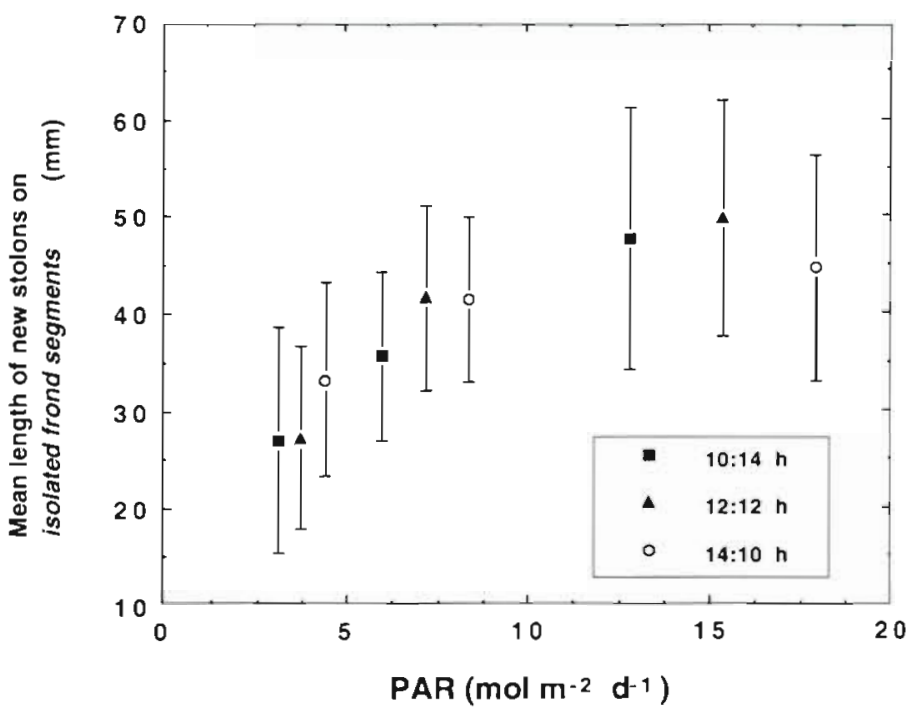

Fig. 9. Mean length \pm SD of new stolons on each isolated frond segment $(n=20)$ after a $10 \mathrm{~d}$ culture period at 3 light intensities $(75,147$ and $\left.281 \mu \mathrm{mol} \mathrm{m}^{-2} \mathrm{~s}^{-1}\right)$ with 3 photoperiods $14: 10 \mathrm{~h}(14: 10,12: 12$ and $10: 14$ h) (light:dark) at $25^{\circ} \mathrm{C}$

On the other hand, the lengths of the new fronds under weak light were greater (Fig. 10).

The variation of irradiation equally affected the morphogenesis of the fronds (Fig. 11). We also observed an elevated development of dichotomously ramified rachis of fronds under weak light on the thallus fragments (after a $10 \mathrm{~d}$ culture period), although the results are not shown here. Likewise, the isolated frond segments developed far more dichotomous ramifications at their apex under weak light (after a $10 \mathrm{~d}$ culture period).

Weak irradiation, for example $1.36 \mathrm{~mol} \mathrm{~m} \mathrm{~m}^{-2}$ $\mathrm{d}^{-1}$, had a positive effect on the number and length of the new pillars of rhizoids on the thallus fragments ( $\mathrm{n}=2$ ) (after a $40 \mathrm{~d}$ culture period) (Fig. 12).

\section{DISCUSSION}

In spite of the large spectrum of temperatures and light intensities used in our experiments, their effects have not indicated great morphological modifications such as those Peterson (1972) and Ohba \& Enomoto (1987) observed for another species of Caulerpa [C. racemosa (Forsskal) J Agardh]. In all the different experimental conditions, the newly developed fronds all present the defined characteristics of the species C. taxifolia (Meinesz et al. 1994b). The morphological plasticity of this species remains weak; this explains the small

Table 2. Results of the Student-Newman-Keuls multiple comparison test ( $\mathrm{df}=61, \mathrm{MSE}=30.0, \alpha=0.05$ ) to examine which light intensity groups equally affect growth of the means of length of new stolons on the thallus fragments cultured at different light intensities (photopenod cycle: $14: 10 \mathrm{~h} \mathrm{light:dark)} \mathrm{at} 25^{\circ} \mathrm{C}$. This test was made because the null hypothesis, homogeneity of means of length among 9 light intensity groups, was rejected by the 1 -way ANOVA test $(\mathrm{df}=8, F=5.12, p<0.0001)$. A, B and $\mathrm{C}$ represent statıstically different groups

\begin{tabular}{|c|c|c|c|c|c|c|c|c|c|}
\hline Light intensity ( $\left.\mu \mathrm{mol} \mathrm{m} \mathrm{m}^{-2} \mathrm{~s}^{-1}\right)$ & 27 & 55 & 62 & 88 & 1.00 & 148 & 160 & 221 & 338 \\
\hline Mean length $(\mathrm{cm})$ & 7.7 & 10.6 & 10.7 & 13.9 & 16.9 & 14.0 & 17.8 & 21.3 & 21.2 \\
\hline \multirow[t]{4}{*}{ Number } & 5 & 6 & 7 & 5 & 14 & 8 & 8 & 9 & 8 \\
\hline & & & & A & A & A & A & A & A \\
\hline & & B & B & B & B & $\mathrm{B}$ & B & & \\
\hline & $\mathrm{C}$ & $\mathrm{C}$ & $\mathrm{C}$ & & C & & & & \\
\hline
\end{tabular}

Table 3. Results of the Student-Newman-Keuls multiple comparison test ( $\mathrm{df}=165, \mathrm{MSE}=119.40, \alpha=0.05$ ) to examine which light intensity groups equally affect growth of the means of length of new stolons on the isolated frond segments $(n=20)$ cultured at different light intensities at $25^{\circ} \mathrm{C}$. This test was made because the null hypothesis, homogeneity of means of length among 9 light intensity groups, was rejected by the 1 -way ANOVA test $(\mathrm{df}=8, F=10.87, \mathrm{p}<0.0001)$. A, B, C and D represent statistically different groups

\begin{tabular}{|c|c|c|c|c|c|c|c|c|c|}
\hline Light intensity (mol m $\mathrm{m}^{-2} \mathrm{~d}^{-1}$ ) & 3.17 & 3.80 & 4.44 & 6.01 & 7.21 & 8.42 & 12.82 & 15.38 & 17.94 \\
\hline Light:dark (h) & $10: 14$ & $12: 12$ & $14: 10$ & $10: 14$ & $12: 12$ & $14: 10$ & $10: 14$ & $12: 12$ & $14: 10$ \\
\hline Mean length $(\mathrm{cm})$ & 27.0 & 27.2 & 33.2 & 35.6 & 41.6 & 41.4 & 47.6 & 49.8 & 44.6 \\
\hline \multirow[t]{5}{*}{ Number } & 20 & 20 & 20 & 20 & 20 & 20 & 20 & 19 & 15 \\
\hline & & & & & $A$ & A & A & $\mathrm{A}$ & A \\
\hline & & & & B & $B$ & B & & & B \\
\hline & & & C & $C$ & C & $\mathrm{C}$ & & & \\
\hline & D & $\mathrm{D}$ & $\mathrm{D}$ & $\mathrm{D}$ & & & & & \\
\hline
\end{tabular}


Fig. 10. Frequency distribution of the new frond length on 2 thallus fragments after a $40 \mathrm{~d}$ culture period at different light intensities. Photoperiod:

$14: 10 \mathrm{~h}$ (light:dark) at $25^{\circ} \mathrm{C}$

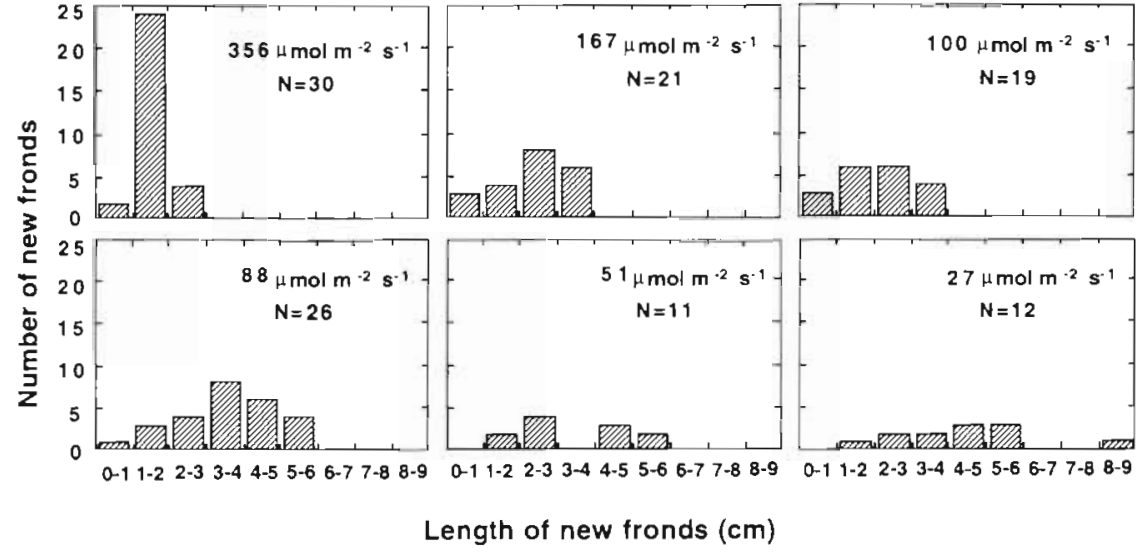

The alga grew with very weak ir radiation (between 1.36 and $1.98 \mathrm{~mol} \mathrm{~m}^{-2} \mathrm{~d}^{-1}$ ). This could explain the distribution of the alga in the Mediterranean Sea at depths ranging from 50 to $99 \mathrm{~m}$ (Belsher \& Meinesz 1995).

It has clearly been established that weak light favors the lengthening of the fronds and dichotomous ramifications of the fronds, which was already obvious in situ (Meinesz \& Hesse 1991, Meinesz et al. 1995). The experiments with the 2 types of cuttings, thallus fragments and isolated frond segments, give the same results; but the use of isolated frond segments is more convenient

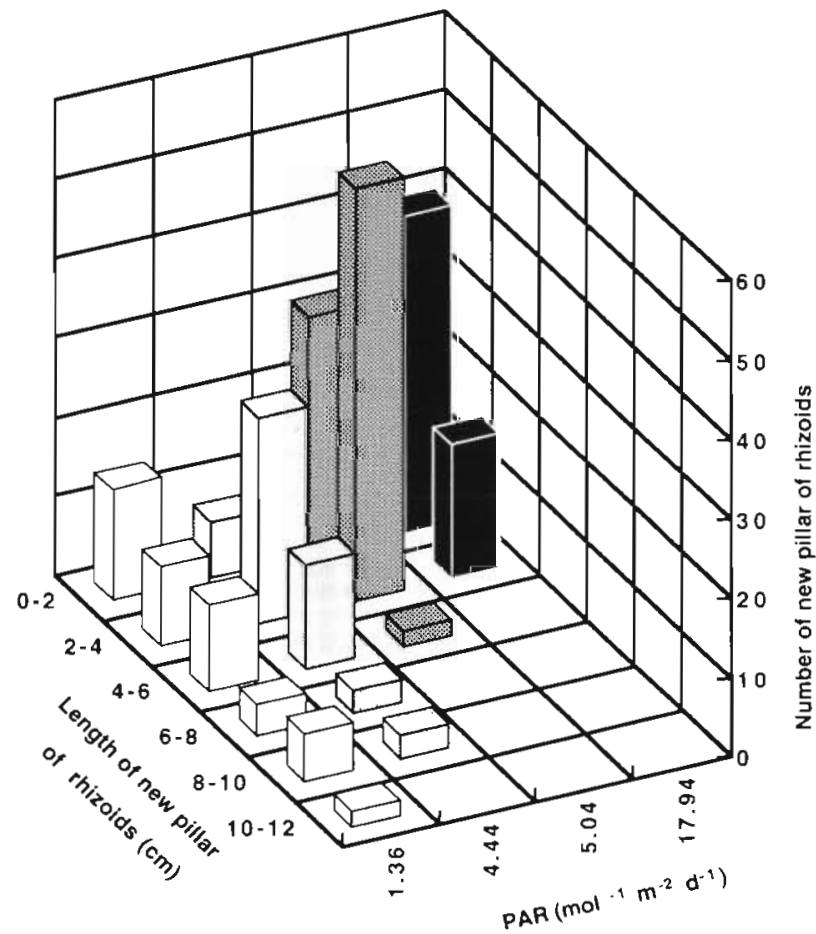

Fig. 12. Frequency distribution of the new pillar of rhizoids (developed on the new stolons) after a $40 \mathrm{~d}$ culture period of 2 thallus fragments at 4 light intensities. Photoperiod: $14: 10 \mathrm{~h}$ (light:dark) at $25^{\circ} \mathrm{C}$ 
for testing the various conditions of growth and development (easier handling, more homogenous samples, and 20 cuttings cultured in the same aquarium).

The upper lethal temperature (between 31.5 and $32.5^{\circ} \mathrm{C}$ ) is well marked. This temperature, never observed in the open Mediterranean Sea, corresponds to the warmest water temperatures of the tropical seas (in open sea) where the alga exists

The lower lethal temperature has been more difficult to define because it varies greatly as a function of the number of days of exposure to cold water temperatures. To experimentally define the lower lethal temperature of the different groups of algae, the following culture periods were taken into consideration: 1 mo for van den Hoek (1982 a, b); 1/2/2 mo for Cambridge et al. (1990). Novaczek et al. (1989) and Cambridge et al. (1991) define the minimum vital temperature experimentally: it is determined when the algae resists a 3 mo culture period.

Van den Hoek (1982b) defined the relationship between the minimum vital temperature obtained experimentally and the isotherms of sea surface temperature. According to him, the experimental vital minimum temperature corresponds to the average temperature of the surface water during the coldest month (February for the Northern Hemisphere).

We could thus define the area of theoretical extension of the introduced strain of Caulerpa taxifolia in the Mediterranean Sea based on this study. It can live between the isotherms of 10 and $31^{\circ} \mathrm{C}$. Noticing that growth and development occur above $15^{\circ} \mathrm{C}$ and that sexual reproduction does not play a major role in the ability of the alga to grow perennially and extensively (Meinesz 1992), the development of populations of the alga can extend in all the regions of Mediterranean Sea. The experimental results concerning the lowest lethal temperature were confirmed by the extension of C. taxifolia colonies in open sea at the northern part of the Golfe du Lion (harbor of Saint-Cyprien, PyrénéesOrientales, France) and at the northern part of the Adriatic Sea (harbor of Malinska, Isle of Krk, Croatia) where the average water temperature of the coldest winter months is between 10 and $11^{\circ} \mathrm{C}$ The latter station is the highest northern latitude $\left(45^{\circ} \mathrm{N}\right)$ at which a population of the genus Caulerpa has been found in the world.

Throughout the year, the greater the number of days above $15^{\circ} \mathrm{C}$ (especially between 20 and $30^{\circ} \mathrm{C}$ ), the more substantial are the growth and development. This experimental report allows one to anticipate an extension of the species into all of the Mediterranean, with a more rapid invasion in the southern regions.

According to the experimental lethal thermal boundaries, the potential thermal distribution of the Mediterranean strain of Caulerpa taxifolia covers all the tropi- cal regions and the warm temperate adjacent seas; it overlapped those of the cosmopolitan red alga species Centroceras clavulatum (C. Agardh) Montagne (van den Hoek \& Breeman 1990, van den Hoek et al. 1990).

The lower lethal temperature found experimentally and observed in situ in the Mediterranean strain of Caulerpa taxifolia is much lower (nearly $10^{\circ} \mathrm{C}$ ) than that of the isothermal limit (about $20^{\circ} \mathrm{C}$ ) corresponding to the distribution of tropical strains of C. taxifolia (Meinesz \& Hesse 1991, Meinesz et al. 1994b). Such a difference, observed in this pantropical species which does not present anomalies of distribution, can only be explained by a genetic characteristic (Meinesz et al. 1994b, Caye et al. 1996). Thus, it is advisable to consider the risk of extension of this vigorous strain in the tropical regions and in the adjacent temperate seas.

Acknowledgements. This work was supported by an EEC grant (DGXI - Life), the French Ministry of Environment, the GIS Posidonie and the Association 'Route des hautes technologies' - Region Provence-AIpes-Cote d'Azur with the cooperative research program of the 'Japanese Society for the Promotion of Science' (JSPS) and French 'Centre National de la Recherche Scientifique' (CNRS). T.K acknowledges the French Ministry of Foreign Affairs for the scholarship of 'Haut niveau' for his research undertaken at the Universite de NiceSophia Antupolis. We thank Christian Visscher of Université de Nice-Sophia Antipolis for critical reading of the English manuscript and Dr Tom Nishida of Japanese National Institute for Far Seas Fisheries for his help with the statistical analysis.

\section{LITERATURE CITED}

Belsher T, Meinesz A (1995) Deep-water dispersal of the tropical alga Caulerpa taxifolla introduced into the Mediterranean. Aquat Bot 51:163-169

Cambridge ML, Breeman AM, Oosterwijk R, van den Hoek C (1984) Temperature responses of some North AtJantic Cladophora species (Chlorophyceae) in relation to their geographical distribution. Helgol Meeresunters 38:349-363

Cambridge ML, Breeman AM, van den Hoek C (1990) Temperature limits at the distribution boundaries of four troptcal to temperate Cladophora species (Cladophorales: Chlorophytal in the North Atlantic Ocean. Aquat Bot 38: $135-151$

Cambridge ML, Breeman AM, van den Hoek C (1991) Temperature responses and distribution of Australian species of Cladophora (Cladophorales: Chlorophyta). Aquat Bot 40:73-90

Carruthers IJB, Walker DI, Huisman JM (1993) Culture studIes on two morphological types of Caulerpa (Chlorophyceael from Perth, Western Australia, with a description of a new species. Bot Mar 36:589-596

Caye G, Chambet P, Delahaye L, Meinesz A, Pletkiewicz D. Ryder K (1996) Différences entre Caulerpa taxifolia de Méditerranée et $C$. taxifolia des mers tropicales. In: Ribera MA, Ballesteros E, Boudouresque CF, Gomez A, Gravez V (eds) 2nd International Workshop on Caulerpa taxifolia. Publicacions Universitat Barcelona, Barcelona, p 171-176

Mernesz A (1992) Mode de dissémunation de l'algue Caulerpa taxifolia introduite en Méditerranée. Rapp PV Réun Comm Int Explor Scient Mer Méditerr 33:B44 
Meinesz A, Ballesteros E, Blachier J, Cinelli F, Cottalorda JM, Frada-Orestano C, Komatsu $T$, Lemée $R$, Molenaar $H$, Morucci C, Pou S, Sandulli R, Tripaldi G, de Vaugelas J (1994a) Latest news on the spread of Caulerpa taxifolia introduced in the Mediterranean. In: 5th Int Phycol Congr, Qingdao, 164:28

Meinesz A, Benichou L, Blachier J, Komatsu T, Lemee R, Molenaar H, Mari X (1995) Variations in the structure, morphology and biomass of Caulerpa taxifolia in the Mediterranean Sea. Bot Mar 38:499-508

Meinesz A, Boudouresque CF (1996) Sur l'origine de Caulerpa taxifolia en Méditerranée. CR Acad Sci Paris Sci Vie 319:603-613

Meinesz A, Hesse B (1991) Introduction et invasion de l'algue tropicale Caulerpa taxifolia en Méditerranée nord-occidentale. Oceanol Acta 14:415-426

Meinesz A, Pietkiewicz D, Komatsu T, Caye G, Blachier J, Lemée R, Renoux-Meunier A (1994b) Notes taxinomiques préliminaires sur Caulerpa taxifolia et Caulerpa mexicana. In: Boudouresque CF, Meinesz A, Gravez V (eds) 1st Int Workshop on Caulerpa taxifolia. GIS Posidonie publications, Marseille, p 105-114

Meinesz. A, Vaugelas J de, Hesse B, Mari X (1993) Spread of the introduced tropical green alga Caulerpa taxifolia in northern Mediterranean waters. $J$ Appl Phycol 5: 141-147

Novaczek 1, Breeman AM, van den Hoek C (1989) Thermal tolerance of Stypocaulon scoparium (Phaeophyta, Sphacelariales) from eastern and western shores of the North Atlantic Ocean. Helgol Meeresunters 43:183-193

Ohba H, Enomoto S (1987) Culture studies on Caulerpa (Caulerpales, Chlorophyceae) II. Morphological variation of C. racemosa var. laetevirens under various culture conditions. Jap J Phycol 35:178-188

This article was submitted to the editor
Peterson RD (1972) Effects of light intensity on the morphology and productivity of Caulerpa racemosa (Forsskal) J Agardh. Micronesica 8(1-2):63-86

Sant N, Delgado O, Rodriguez-Prieto C, Balesteros E (1994) The effects of dessication on photosynthesis of Caulerpa taxifolia (Vahl) C. Agardh. In: Boudouresque CF, Meinesz A, Gravez $V$ (eds) 1st Int Workshop on Caulerpa taxifolia. GIS Posidonie publicatıons, Marseille, p 315-319

van den Hoek C (1982a) Phytogeographuc distribution groups of benthic marine algae in the North Atlantic Ocean. A review of experimental evidence from life history studies. Helgol Meeresunters 35:153-214

van den Hoek C (1982b) The distribution of benthic marine algae in relation to the temperature regulation of their life histories. Biol J Linn Soc 18(2):81-144

van den Hoek C. Breeman AM (1990) Seaweed bıogeography of the north Atlantic: where are we now? In: Garbary DJ, South GR (eds) NATO ASI Series, G22: evolutionary biogeography of the marine algae of the North Atlantic. Springer-Verlag, Berlin, p 55-86

van den Hoek C, Breeman AM, Stam WT (1990) The geographic distribution of seaweed species in relation to temperature: present and past. In: Beukema JJ, Wolff WJ, Brouns JJWM (eds) Expected effects of climatic change on marine coastal ecosystems. Kluwer Academic Publications, Dordrecht, p 55-67

Yarish C, Breeman AM, van den Hoek C (1984) Temperature light and photoperiod responses of some northeast American and west European endemic rhodophytes in relation to their geographical distribution. Helgol Meeresunters 38:273-304

Yarish C, Breeman AM, van den Hoek C (1986) Survial strategies and temperature responses of seaweeds belonging to different biogeographic distribution groups Bot Mar 29:215-230

Manuscript first received: July 2, 1996

Revised version accepted: November 15, 1996 